\title{
Setting of reliable immunohistochemical criteria for the recurrence of nodular basal cell carcinoma
}

\author{
N.Yu. Orlinskaya, D.V. Davydenko, I.L. Shlivko, O.E. Garanina \\ Privolzhsky Research Medical University of the Ministry of Health of Russia, Nizhny Novgorod, Russia
}

Introduction. Basal cell carcinoma (BCC) is one of the most prevalent skin neoplasms with increasing incidence. The grade of BCC malignancy is highly variable and depends on the invasiveness and recurrence potential. The study was aimed at identification of immunohistochemical (IHC) determinants of BCC recurrence.

Materials and methods. The comparative study encompassed 10 cases of primary BCC and 10 cases of recurrent BCC. The panel of immunohistochemical targets included p53, CK8/18, Bcl-2, CK19, Collagen type IV, Desmin, CD8, Ki-67, Vimentin, VEGFR, EGFR and AR.

Results. Diffuse expression of vimentin (characteristic of both primary and recurrent BCCs and clearly indicating the border between the tumor stroma and the surrounding dermis) in the recurrent tumors was twice as strong as in the primary tumors. Immunohistochemistry for collagen type IV revealed different nature of the basement membrane alterations in the primary and recurrent tumors. A two-fold increase in the intensity of angiogenesis observed in the recurrent tumors was accompanied by a more than two-fold significant increase in the androgen receptor protein expression.

Conclusion. Increasing grade of BCC malignancy is associated with the immunohistochemically revealed reinforcement of the stromal and vascular components of the tumor, as well as progressive destruction of the basement membrane along with the increased expression of androgen receptor protein by tumor cells.

Keywords: basal cell carcinoma, recurrence, immunohistochemistry

Corresponding author: Natalia Yu. Orlinskaya. E-mail: orlinskaya@rambler.ru

For citation: Orlinskaya N.Yu., Davydenko D.V., Shlivko I.L., Garanina O.E. Setting of reliable immunohistochemical criteria for the recurrence of nodular basal cell carcinoma. Clin. exp. morphology. 2020;9(3):43-49. DOI:10.31088/CEM2020.9.3.43-49.

Funding. The work was carried out within the framework of State Assignment to Privolzhsky Research Medical University of the Ministry of Health of Russia «Development of diagnostic methods and presonalized methods for the treatment of malignant skin tumors based on the methods of fluorescence bioimaging and fluorescence imaging in the near and K-band» (No. AAAA-A18-118052190081-8).

Conflict of interest. The authors declare no conflict of interest.

Received 25.11.2019. Received in revised form 20.05.2020. Accepted 29.06.2020.

УДК 616-006.63

\section{Иммуногистохимические критерии рецидивирования базально-клеточной карциномы нодулярного строения}

Н.Ю. Орлинская, Д.В. Давыденко, И.Л. Шливко, О.Е. Гаранина

ФГБОУ ВО Приволжский исследовательский медицинский университет Минздрава России, Нижний Новгород, Россия

Введение. Базально-клеточная карцинома является одним из самых частых новообразований кожи и имеет тенденцию к повышению уровня заболеваемости. Среди критериев злокачественности этой группы новообразований нужно отметить ее инвазивный потенциал и способность к рецидивному росту. Цель исследования - определить иммуногистохимические особенности стромального компонента базально-клеточных карцином для прогноза рецидивирования.

Maтериалы и методbl. В исследуемую группу вошли 10 случаев первичных и 10 случаев рецидивных базально-клеточных карцином. Для иммуногистохимического исследования использовали панель антител, включающую в себя следующие маркеры: p53, CK8/18, Bcl-2, CK19, Collagen IV, Desmin, CD 8, Ki-67, Vimentin, VEGFR, EGFR, Androgen receptor.

Результаты. По данным гистологического и иммуногистохимического исследования экспрессия виментина, носящая диффузный характер в первичных и рецидивных опухолях, не только позволила 
четко определить границу опухолевой стромы и окружающей дермы, но и в 2 раза отличалась по количественным значениям. Экспрессия коллагена IV типа показала различный характер изменений базальной мембраны в первичных и рецидивных опухолях. В рецидивных опухолях было установлено усиление ангиогенеза в 2 раза. Экспрессия андрогенов также показала достоверную разницу более чем в 2 раза.

Заключение. По мере нарастания агрессивных свойств базально-клеточного рака кожи возрастает экспрессия антигенов основных волокнистых стромальных структур, увеличивается индекс пролиферативной активности, происходит усиление ангиогенеза.

Ключевые слова: базально-клеточная карцинома, рецидив, иммуногистохимия

Для корреспонденции: Наталья Юрьевна Орлинская. E-mail: orlinskaya@rambler.ru

Для цитирования: Орлинская Н.Ю., Давыденко Д.В., Шливко И.Л., Гаранина О.Е. Иммуногистохимические критерии рецидивирования базально-клеточной карциномы нодулярного строения. Клин. эксп. морфология. 2020;9(3):43-49. DOI: 10.31088/CEM2020.9.3.43-49

Финансирование. Исследование выполнено в рамках государственного задания Приволжского исследовательского медицинского университета Минздрава России «Разработка способов диагностики и персонифицированных методов лечения злокачественных новообразований кожи на основании методов флуоресцентного биоимиджинга и флуоресцентной визуализации в ближнем и К-диапазоне» (№ AAАA-А18-118052190081-8).

Конфликт интересов. Авторы заявляют об отсутствии конфликта интересов.

Статья поступила 10.12.2019. Получена после рецензировании 03.02.2020. Принята в печать 14.05.2020.

\section{Introduction}

Basal cell carcinoma (BCC; synonyms: basalioma, basal cell epithelioma) is the most prevalent malignant tumor of the skin. According to the WHO Classification of Skin Tumors (2018), BCCs (which consist of basaloid cells) are classified as truly malignant as they show uncontrolled growth with infiltration and destruction of the underlying tissues, which also allows classifying them as tumors with locally destructive growth [1]. BCC can develop at any age, but is predominantly seen in patients over $50[2,3]$. Despite the wide variety of clinical and morphological variants, the prevalent form of $\mathrm{BCC}$ $(42.8 \%)$ is nodular [4]. The nodular variants constitute $60-80 \%$ of all basal cell skin cancers [1].

The recurrence of tumors of this subgroup varies from $2-7 \%$ to $13.6-21.6 \%$ and is practically independent of the method of treatment during the first year after the therapy. The tumor recurs in $40 \%$ of the patients within 10 years after the treatment, and the cases of long-term (measured in years) ineffective therapy for basalioma are common. The multiplicity of factors for basalioma recurrence have been described, including large tumor size and the infiltrative-ulcerative type of growth with deep invasion and perineural expansion. Localization of the tumor is considered no less significant, with skin of the nose, nasolabial triangle, or lower eyelid with the involvement of the intermarginal strip being most susceptible to basalioma recurrence. The recurrence rate also increases with the development of a malignant focus against the background of precancerous skin lesions. Certain functional correlates of $\mathrm{BCC}$ recurrence propensity have been described as well, e.g. the elevated expression of vascular endothelial growth factor and its cognate receptor (VEGF/VEGFR) by tumor cells accompanied by high proliferative activity (indicated by increased expression of and $\mathrm{Ki}-67$ ) and altered expression of major regulators of apoptosis ( $\mathrm{p} 53, \mathrm{bcl}-2)$. Nevertheless, none of the suggested mechanisms provides unambiguous explanation for the emergence of a localized process of the persistently recurrent nature [5-10]. Such a gap in knowledge makes the diagnosis and treatment of BCC a high-priority interdisciplinary focus of clinical dermatology, oncology and pathomorphology.

In this comparative study, we aimed at identification of immunohistochemical (IHC) determinants of BCC recurrence.

\section{Materials and Methods}

The study encompassed 10 cases of primary $\mathrm{BCC}$ and 10 cases of recurrent BCC in patients of the Center for Diagnostics and Treatment of Skin Tumors of the Privolzhsky Research Medical University. Surgical treatment with the excision of a primary or recurrent tumor was based on clinical indications. The total sample included 8 men and 12 women, aged $72.5 \pm 13.1$ years on average. In the group of patients with primary tumors, no recurrence episodes were observed for 3 years after the surgery. In the group of patients with recurrent BCCs, the recurrence emerged within 1-2.5 years after the surgery.

The surgical specimens were fixed in $10 \%$ formalin. The resection was performed with mandatory inking of the margins to determine the presence or absence of invasive growth. Routine histological processing of the material was implemented with the use of Excelsior ES tissue processor (Thermo Scientific, USA). The dehydrated specimens were embedded in paraffin with the use of HistoStar embedding workstation (Thermo Scientific), sectioned with the use of HM 325 rotary microtome (Thermo Scientific) at a 4-6 $\mu \mathrm{m}$ thickness and stained with H\&E with the use of Gemini AS automated slide stainer (Thermo Scientific).

The IHC staining was carried out in a BOND-MAX automated module (Leica Biosystems, Germany). 

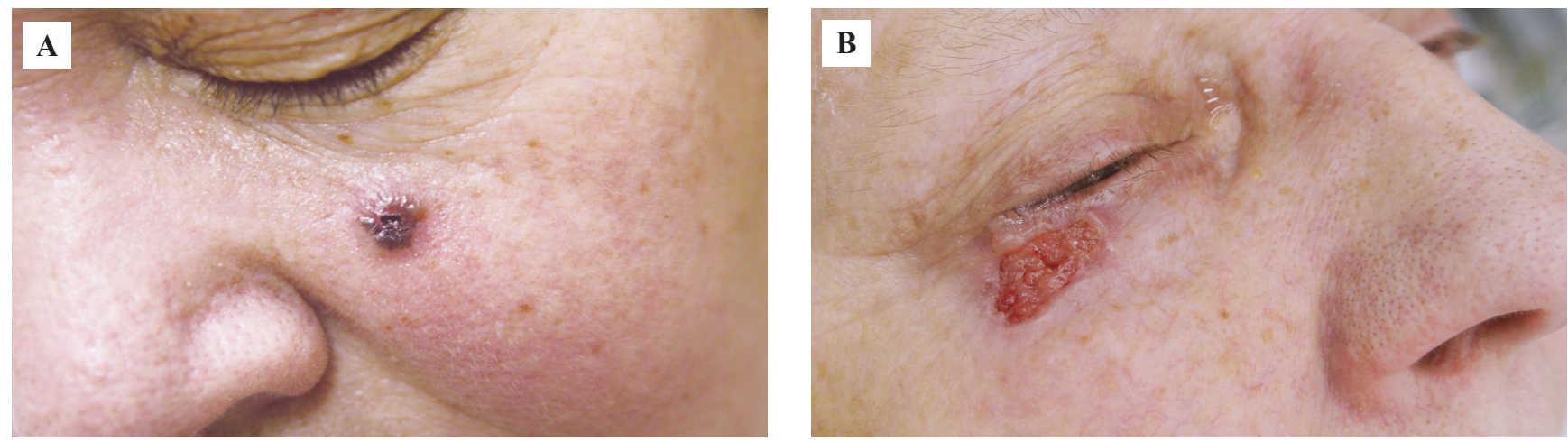

Figure 1. Clinical images of (A) - nodular basal cell carcinoma, (B) nodular basal cell carcinoma with ulcus rodens

Puc. 1. Клиническое изображение. А - узловая форма базально-клеточного рака, В - ulcus rodens при узловой форме базально-клеточного рака

The panel of antibodies used for IHC is given in Table 1.

The morphometry was carried out with the use of Leica DM2500 optical microscope (Leica, Germany).

The expression of antigens was evaluated by counting positively stained cells in 10 fields of view at a $\times 400$ magnification. The expression indexes were calculated as the number of positive cells $\times 100 /$ total cell number.

The Mann-Whitney U-test was used to identify differences in the studied parameters between independent groups. The results are represented as median values (Me, Q50\%) complemented with Q25\% and Q75\% values.

\section{Results and Discussion}

In the studied cases, the nodular form of basal cell carcinoma was most frequently localized in the skin of the face and scalp, less often in the skin of the trunk, in $20 \%$ and $80 \%$ respectively. The tumor was more frequently represented by the single nodular pink or gray-pink formation of a hemispherical shape, the peripheral edge of which was surrounded by a ridge consisting of small "pearls" (Figure 1A) [11, 12]. Erosions or ulcers covered with a dark brown hemorrhagic crust were repeatedly found in the center of the tumor. In case of extensive ulceration

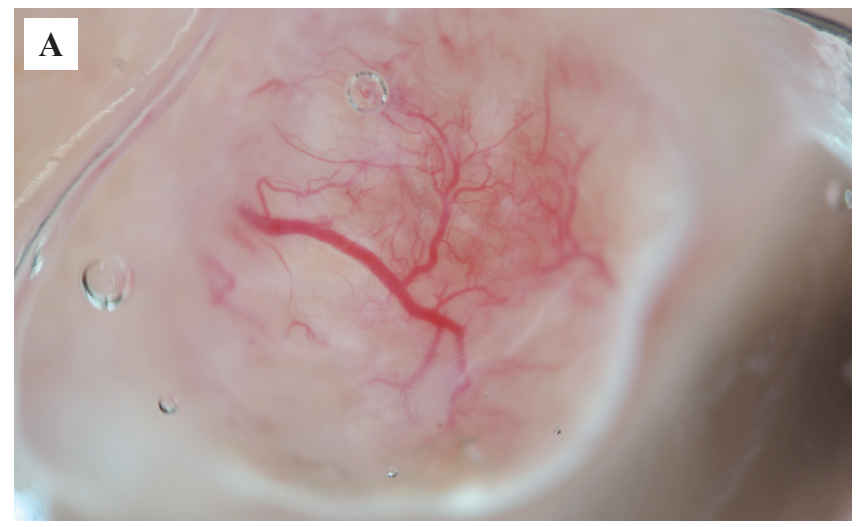

Table 1 | Таблица 1

The panel of antibodies used in the study Панель антител, используемых в исследовании

\begin{tabular}{|c|c|c|c|}
\hline & $\begin{array}{c}\text { Title | } \\
\text { Название }\end{array}$ & $\begin{array}{c}\text { Clone | } \\
\text { Клон }\end{array}$ & $\begin{array}{l}\text { Manufacturer | } \\
\text { Производитель }\end{array}$ \\
\hline $\begin{array}{l}\text { Mouse | } \\
\text { Мышиные }\end{array}$ & $\begin{array}{l}\text { p53 } \\
\text { CK8/18 } \\
\text { Bcl-2 } \\
\text { CK19 } \\
\text { Collagen IV } \\
\text { Desmin } \\
\text { CD } 8\end{array}$ & $\begin{array}{l}\text { Do7 } \\
\text { 5D3 } \\
124 \\
\text { Ks19.1 } \\
\text { CIV22 } \\
\text { D33 } \\
\text { 4B11 }\end{array}$ & $\begin{array}{l}\text { Novocastra, UK } \\
\text { Novocastra, UK } \\
\text { Dako, Denmark } \\
\text { Lab Vision Corporation, } \\
\text { USA } \\
\text { Cell Marque, USA } \\
\text { Lab Vision Corporation, } \\
\text { USA } \\
\text { Novocastra, UK }\end{array}$ \\
\hline $\begin{array}{l}\text { Rabbit | } \\
\text { Кроличьи }\end{array}$ & $\begin{array}{l}\text { Ki-67 } \\
\text { Vimentin } \\
\text { VEGFR } \\
\text { EGFR } \\
\text { Androgen } \\
\text { receptor }\end{array}$ & $\begin{array}{l}\text { SP6 } \\
\text { SP20 } \\
\text { Poly } \\
\text { EP38Y } \\
\text { poly }\end{array}$ & $\begin{array}{l}\text { Diagnostic Biosystems, } \\
\text { Netherlands } \\
\text { Lab Vision Corporation, } \\
\text { USA } \\
\text { Diagnostic Biosystems, } \\
\text { Netherlands } \\
\text { Lab Vision Corporation, } \\
\text { USA } \\
\text { Lab Vision Corporation, } \\
\text { USA }\end{array}$ \\
\hline
\end{tabular}

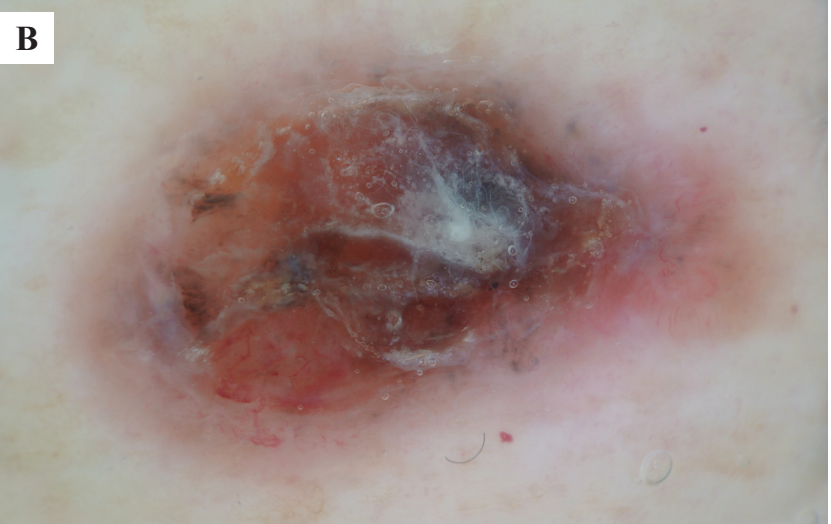

Figure 2. Dermatoscopy images of (A) - nodular basal cell carcinoma, (B) - pigmented nodular basal cell carcinoma

Puc. 2. Дерматоскопическое изображение. А - узловая форма базально-клеточного рака, В - пигментированная узловая форма базально-клеточного рака 
with central necrosis, it was diagnosed as an ulcerative form or a corroding ulcer (ulcus rodens) (Figure 1B).

The dermatoscopy images of nodular BCCs in the studied cohort revealed the presence of large tree-like vessels of a bright-red color, the areas of erosion or ulceration covered with a dark-brown hemorrhagic scab, and bluish-gray ovoid structures and globules with pigmentation (Figure 2 A, B). Upon macroscopic examination of the surgical specimens, primary BCCs were distinguished by large size of nodular formations and smooth surface exhibiting telangiectasias. In primary BCCs, the entire tumor focus was represented by a solitary nodule with tuberous surface or an ulcerated core walled with a scalloped array of nodulary elements (Figure 3).

Histological examination of the tumors revealed small basaloid cells - intensely stained, with compact rounded or oval nuclei. The H\&E staining revealed neither specific structural features of the chromatin nor nucleoli; the cytoplasm, usually basophilic, was scarce. The periphery of the foci was occupied by zones of larger prismatic cells with oval, slightly elongated nuclei and characteristic palisade arrangement, regarded as a key histological determinant of BCC. The tumor cells showed no intercellular bridges but contained mitotic figures. The fibro-cellular connective tissue stroma of the tumor was organized in bundles which divided the cellular complexes into lobules separated from the metachromatic mucoid substance rich in glycosaminoglycans and comprising the infiltrates of lymphocytes, basophils and plasma cells. In slides, the epithelial tumor complexes were frequently separated from the stroma by characteristic clefts classified as retraction artifacts typical for BCC (Figure 4).

The overall dimensions of the neoplasms ranged from 0.5 to $2.5 \mathrm{~cm}$. The invasion was confined to the dermis in all cases. The distance from the tumor to the closest resection margin ranged from 0.1 to $0.15 \mathrm{~mm}$. The resection margins were tumor-negative in all cases, and no signs of perineural invasion were observed. The groups of primary and recurrent tumors were further compared by IHC criteria (Table 2).

Proliferative activity of primary and recurrent BCCs was characterized by uniform distribution of Ki-67-positive tumor cells which amounted to $26 \%$ in primary tumors and $46 \%$ in recurrent tumors $(p=0.0023$, Figure 5$)$. The vimentin expression was diffuse and provided a clear demarcation of the border between the tumor stroma and the surrounding dermis. The content of vimentin-positive cells in primary BCCs $(20 \%)$ was lower than in recurrent BCCs $(47 \%, p=0.026$, Figure 6$)$. We do not as-

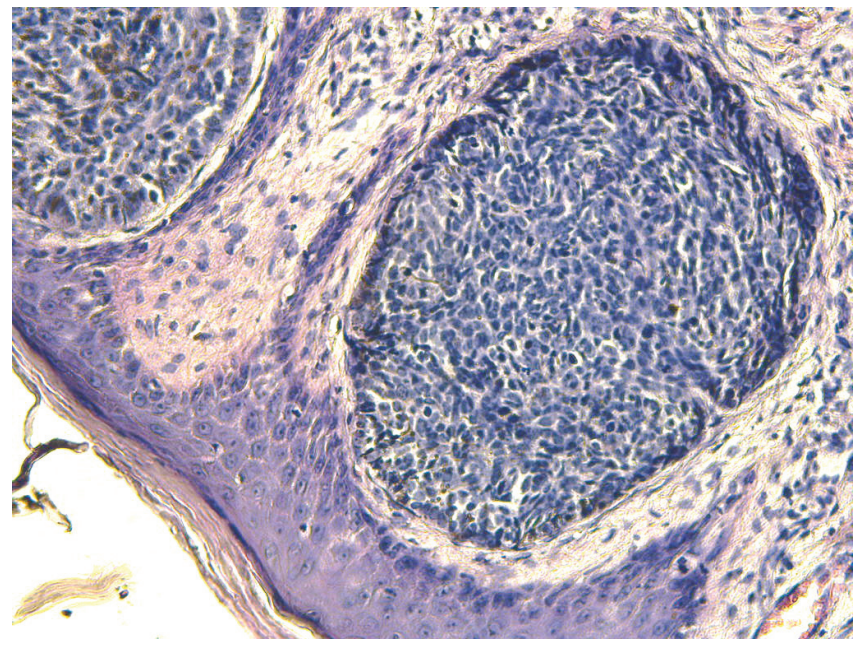

Figure 4. Routine histology of nodular basal cell carcinoma. H\&E, magnification $\times 200$

Puc. 4. Гистологическая картина узловой формы базальноклеточной карциномы. Окраска гематоксилином и эозином, $\times 200$ 

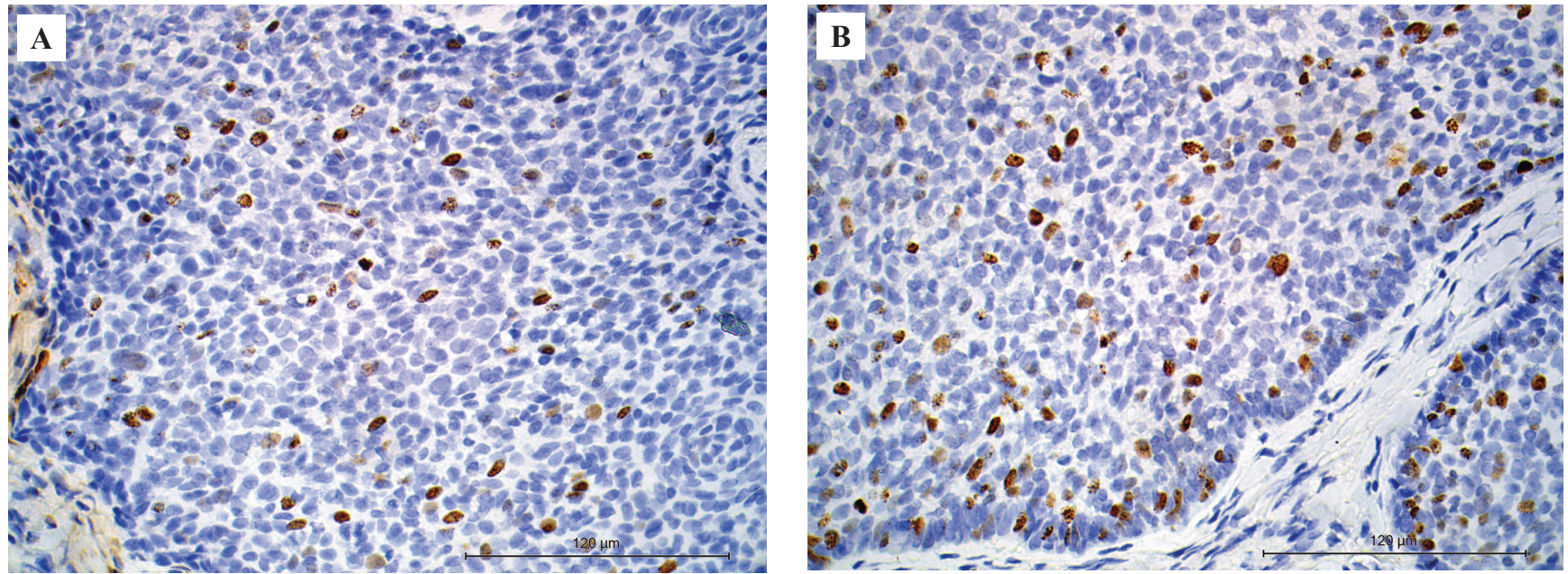

Figure 5. Ki-67 protein expression in (A) - primary BCCs, (B) - recurrent BCCs. Immunohistochemistry, magnification $\times 400$

Puc. 5. Экспрессия Кі-67 в первичных (А) и рецидивных (В) опухолях. ИГХ окрашивание, ×400
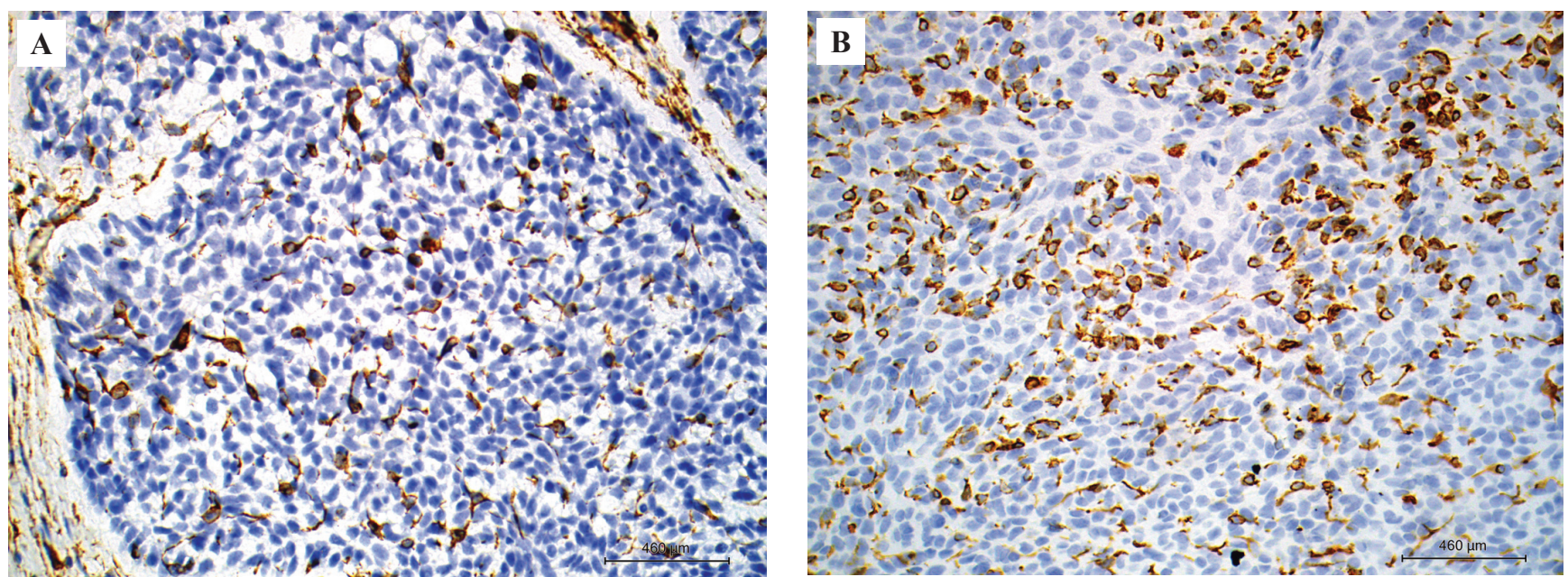

Figure 6. Vimentin protein expression in (A) - primary tumors, (B) - recurrent tumors. Immunohistochemistry, magnification $\times 400$

Puc. 6. Экспрессия виментина в первичных опухолях (А) по сравнению с рецидивными опухолями (B). ИГХ окрашивание, $\times 400$
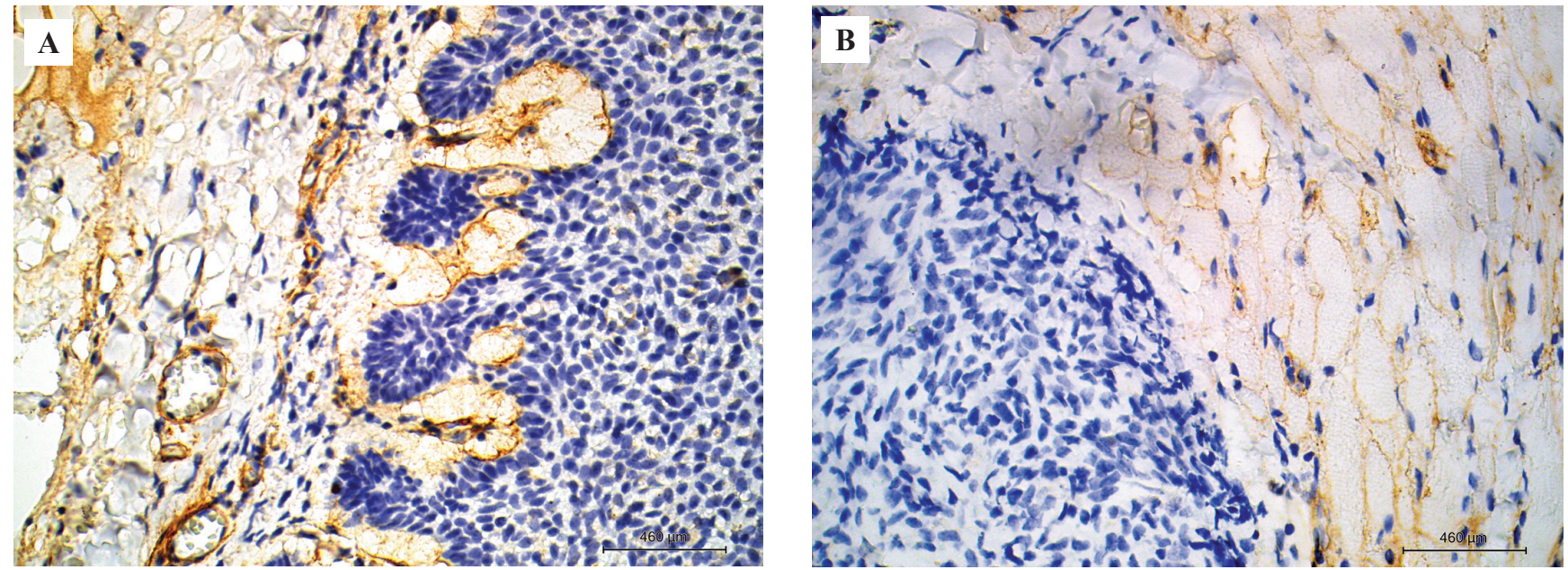

Figure 7. IHC image for collagen type IV revealing (A) - ruptures of the basement membrane in primary tumors, (B) - destruction of the basement membrane in recurrent tumors. Immunohistochemistry, magnification $\times 400$

Puc. 7. Коллаген IV типа. Разрыв базальной мембраны в первичных опухолях (А), отсутствие базальной мембраны в рецидивных опухолях (В). ИГХ окрашивание, $\times 400$ 
Table 2 | Таблииа 2

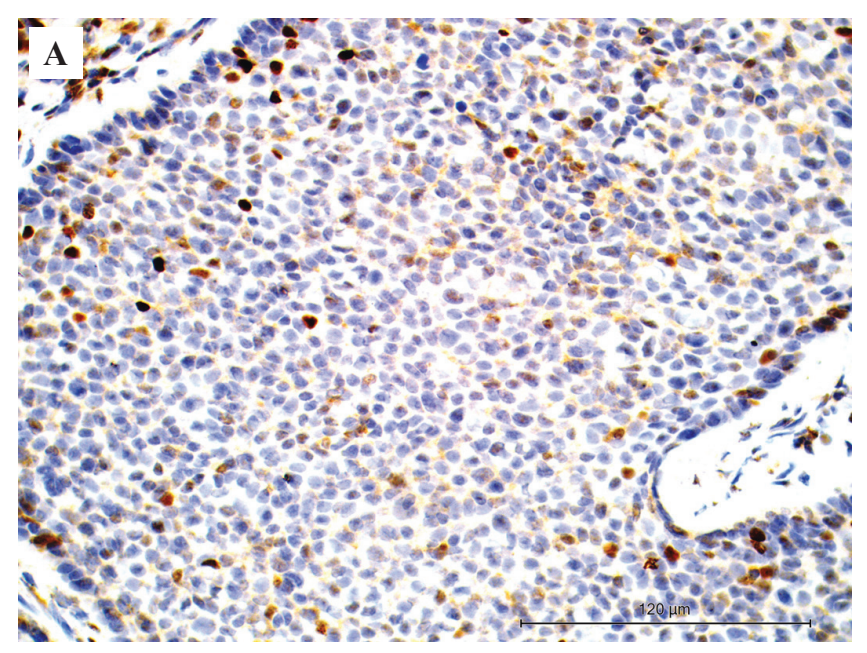

Comparative immunohistochemical characteristic of primary and recurrent basal cell carcinomas (BCC) |

Сравнительная иммуногистохимическая характеристика первичного и рецидивного базального-клеточного рака (БКР)

\begin{tabular}{|c|c|c|}
\hline $\begin{array}{l}\text { IHC marker | } \\
\text { ИГХ маркер }\end{array}$ & $\begin{array}{c}\text { Primary ВСС } \\
(n=10) \mid \\
\text { Первичный БКР } \\
(n=10)\end{array}$ & $\begin{array}{c}\text { Recurrent ВСС } \\
(\mathrm{n}=10) \mid \\
\text { Рецидивный БКР } \\
(\mathrm{n}=10)\end{array}$ \\
\hline p53 & $35 \pm 4,2 \%$ & $35 \pm 3,4 \%$ \\
\hline $\mathrm{Ki}-67$ & $26 \pm 2,9 \%$ & $46 \pm 3,7 \%$ \\
\hline Bcl-2 & + & + \\
\hline CK8/18 & +++ & +++ \\
\hline CK19 & - & - \\
\hline $\begin{array}{l}\text { Collagen } \\
\text { type IV | } \\
\text { Коллаген } \\
\text { IV типа }\end{array}$ & $\begin{array}{c}+ \\
\text { (basal membrane } \\
\text { with ruptures) } \mid \\
\text { (базальная мембрана } \\
\text { с разрывами) }\end{array}$ & $\begin{array}{c}++ \\
\text { (there is no basal } \\
\text { membrane) } \mid \\
\text { (базальная мембрана } \\
\text { отсутствует) }\end{array}$ \\
\hline Vimentin & $20 \pm 6,1 \%$ & $47 \pm 5,3 \%$ \\
\hline Desmin & - & - \\
\hline EGFR & $26 \pm 1,9 \%$ & $46 \pm 2,4 \%$ \\
\hline $\mathrm{CD} 8$ & - & - \\
\hline $\begin{array}{l}\text { Androgen } \\
\text { receptor | } \\
\text { Рецепторы } \\
\text { андрогенов }\end{array}$ & $15 \pm 3,9 \%$ & $42 \pm 4,2 \%$ \\
\hline VEGF & $12 \pm 4,8 \%$ & $32 \pm 4,2 \%$ \\
\hline
\end{tabular}

sociate the expression of vimentin with the presence of melanocytes, as the study involved unpigmented forms of the tumor.

IHC with antibodies to collagen type IV revealed ruptures of the basement membrane in primary tumors and its complete absence in recurrent tumors (Figure 7).

The content of androgen receptor-positive cells in the nodules of primary BCCs (15\%) was lower compared with recurrent BCCs $(42 \%, \mathrm{p}=0.002$, (Figure 8).

IHC for vascular endothelial growth factor receptor (VEGFR) revealed diffuse staining of clustered tumor cells in all cases; the increased content of positive cells in recurrent BCCs $(32 \%$ compared to $12 \%$ in the primary tumors) indicates the elevated rates of angiogenesis in the recurrent neoplasms.

\section{Conclusion}

The study identified significant IHC determinants of $\mathrm{BCC}$ recurrence, including the increased Ki-67 index, progressive destruction of the basement membrane, and the increased expression of vimentin, EGFR, VEGFR and notably the androgen receptor (AR).

No differences in the expression of apoptosis-related regulatory proteins (p53, bcl-2) were observed between the groups. The expression of CK8/18 was ubiquitous; the staining for CK19, Desmin and CD8 was weak and showed no difference between the groups. The study revealed no clear correlation between the size of BCC and its aggressive properties. The possibility of using AR as a diagnostic marker or therapeutic target in $\mathrm{BCCs}$ requires further investigation. 


\section{Author contributions}

N.Yu.O, I.L.S. and O.E.G. conceived the study and designed the experiments;

O.E.G., N.Yu.O. and D.V.D collected the data and performed the analysis;

N.Yu.O., D.V.D., I.L.S. and O.E.G. wrote the manuscript;

D.V.D. edited the manuscript.

\section{References}

1. WHO classification of skin tumors. International Agency for Research on Cancer, 2018.

2. Patterson JW. Weedon's skin pathology. 4th ed. London: Churchill-Livingstone, 2016. P. 806-11.

3. Cernea CR, Ferraz AR, de Castro IV, Sotto MN, Logullo AF, Bacchi $C E$ et al. p53 and skin carcinomas with skull base invasion: a case-control study. Otolaryngol Head Neck Surg. 2006;134(3):471-5. DOI: 10.1016/j.otohns.2005.10.030.

4. Collins SA. Clinical presentation. In: Miller SJ, Maloney ME (eds.). Cutaneus oncology. Blackwell Science: Malden, MA, 1998. P. 625-32.

5. Kaur P, Mulvaney M, Carlson JA. Basal cell carcinoma progression correlates with host immune response and stromal alterations: a histologic analysis. Am J Dermatopathol. 2006;28(4):293-307. DOI: 10.1097/00000372-200608000-00002.
6. Panuncio A, Vignale R, Lopez G. Immunohistochemical study of nerve fibres in basal cell carcinoma. Eur J Dermatol. 2003; 13(3):250-3.

7. LeBoit PE, Burg G, Weedon D, Sarasin A (eds.). Pathology and genetics of skin tumors. WHO classification of tumors. Lyon: IARCPress, 2006. 357 p.

8. Quatresooz P, Martalo O, Piérard GE. Differential expression of alpha1 (IV) and alpha5 (IV) collagen chains in basal-cell carcinoma. J Cutan Pathol. 2003;30(9):548-52. DOI: 10.1034/j.16000560.2003.00118.x.

9. Bertheim U, Hofer PA, Engström-Laurent A, Hellström S. The stromal reaction in basal cell carcinomas. A prerequisite for tumour progression and treatment strategy. Br J Plast Surg. 2004;57(5):429-39. DOI: 10.1016/j.bjps.2003.12.024.

10. Habet JM. Cellular immunopathology. In: Miller SJ, Maloney ME (eds.). Cutaneus oncology. Blackwell Science: Malden, MA, 1998. P. 599-601.

11. Dourmishev LA, Rusinova D, Botev I. Clinical variants, stages, and management of basal cell carcinoma. Indian Dermatol Online J. 2013;4(1):12-7. DOI: 10.4103/2229-5178.105456.

12. Scrivener Y, Grosshans E, Cribier B. Variations of basal cell carcinomas according to gender, age, location and histopathological subtype. Br J Dermatol. 2002;147(1):41-7. DOI: 10.1046/j.13652133.2002.04804.x.

\section{Author information}

Natalia Yu. Orlinskaya - Dr. Sci. (Med.), Professor, Head of the Department of Pathological Anatomy, University Clinic, Privolzhsky Research Medical University. http://orcid.org/0000-0003-2896-2968

Dina V. Davydenko - Cand. Sci. (Biol.), Researcher of the Department of Pathological Anatomy, University Clinic, Privolzhsky Research Medical University. http://orcid.org/0000-0002-8339-1291

Irena L. Shlivko - Dr. Sci. (Med.), Head of the Department of Skin and Sexually Transmitted Diseases, Privolzhsky Research Medical University.

https://orcid.org/0000-0001-7253-7091

Oksana E. Garanina - Cand. Sci. (Med.), Oncologist, Dermatovenerologist, Research, Assistant of the Department of Skin and Sexually Transmitted Diseases, Privolzhsky Research Medical University.

http://orcid.org/0000-0002-7326-7553 